\title{
PENGARUH LEVERAGE DAN PROFITABILITAS TERHADAP PENGUNGKAPAN TANGGUNG JAWAB SOSIAL PERUSAHAAN PERTAMBANGAN YANG TERDAFTAR DI BURSA EFEK INDONESIA
}

\author{
Oleh \\ Denny Andriana \\ ( Dosen Program Studi Akuntansi Universitas Pendidikan Indonesia)
}

\begin{abstract}
Abstrak
Penelitian ini bertujuan untuk menguji karakteristik perusahaan, diantaranya adalah leverage dan profitabilitas, dan pengaruhnya terhadap pengungkapan tanggung jawab sosial perusahaan pertambangan yang terdaftar di Bursa Efek Indonesia (BEI). Indikator pengungkapan tanggung jawab sosial perusahaan mengacu pada pedoman Global Reporting Initiatives (GRI) 2000. Pengamatan yang dilakukan terhadap 30 perusahaan pertambangan yang terdaftar di BEI untuk periode 2009 - 2011 mengacu pada metode purposive sampling yang dilakukan pada penelitian ini, menghasilkan 13 perusahaan yang menjadi sampel penelitian. Teknik analisis data yang digunakan dalam penelitian ini adalah regresi linier berganda. Hasil pengujian membuktikan bahwa leverage berpengaruh negatif namun gagal menunjukkan pengaruh signifikan terhadap pengungkapan tanggung jawab sosial perusahaan. Variabel profitabilitas di lain pihak berhasil membuktikan pengaruh positif terhadap pengungkapan tanggung jawab sosial perusahaan namun pengaruh tersebut tidak signifikan.
\end{abstract}

Kata kunci: leverage, profitabilitas, pengungkapan tanggung jawab sosial perusahaan

\section{Pendahuluan}

Tanggung jawab sosial perusahaan di Indonesia atau lebih dikenal dengan istilah corporate social responsibility (CSR), telah di atur di dalam Undang Undang Perseroan Terbatas tahun 2007 pasal 74 ayat 1 yang menyatakan bahwa "Perseroan yang menjalankan kegiatan usahanya di bidang dan/atau berkaitan dengan sumber daya alam wajib melaksanakan tanggung jawab sosial dan lingkungan".

Atas pelaksanaan tanggung jawab sosial perusahaan tersebut juga perlu diungkapkan dalam laporan yang dikeluarkan oleh perusahaan. Pengungkapan tanggung jawab sosial perusahaan merupakan proses pengkomunikasian dampak sosial dan lingkungan dari kegiatan ekonomi perusahaan terhadap masyarakat. (Rustiarini, 2012).

Pengungkapan tanggung jawab sosial perusahaan juga tercantum dalam Pernyataan Standar Akuntansi Keuangan No. 1 tahun 2009 (revisi 1998) paragraf 09 yaitu "Perusahaan dapat pula menyajikan laporan tambahan seperti laporan mengenai lingkungan hidup laporan nilai tambah, khususnya bagi industri di mana faktor-faktor lingkungan hidup memegang peranan penting bagi industri 
yang menganggap pegawai sebagai kelompok pengguna laporan yang memegang peranan penting".

Perusahaan - perusahaan yang terdaftar di Bursa Efek Indonesia memiliki kewajiban untuk menyampaikan laporan tahunan yang salah satu isinya kewajiban dalam laporan tersebut mengenai uraian aktivitas dan biaya yang dikeluarkan berkaitan dengan tanggung jawab sosial perusahaan terhadap masyarakat dan lingkungan. (Keputusan Ketua Bapepam dan LK No. Kep-134/BL/2006).

Penelitian ini bertujuan untuk mengetahui adanya pengaruh karakteristik perusahaan yang terdaftar di Bursa Efek Indonesia, khususnya perusahaan pertambangan, terhadap jumlah pengungkapan tanggung jawab sosial perusahaan. Karakteristik perusahaan yang diduga mempengaruhi jumlah pengungkapan tanggung jawab sosial perusahaan dalam penelitian ini adalah leverage dan profitabilitas. Sedangkan jumlah pengungkapan tanggung jawab sosial perusahaan akan mengacu pada pedoman yang dikeluarkan Global Reporting Initiatives (GRI).

Hasil penelitian ini diharapkan dapat memberikan tambahan pengetahuan dan wawasan mengenai faktor - faktor yang mempengaruhi jumlah pengungkapan tanggung jawab sosial perusahaan dalam laporan tahunan perusahaan pertambangan yang tercatat di Bursa Efek Indonesia. Manfaat praktis penelitian ini adalah untuk memberikan informasi berguna bagi para pembaca yang tertarik dengan hal - hal yang berhubungan dengan tanggung jawab sosial perusahaan.

\section{Kajian Pustaka}

Tanggung jawab sosial merupakan mekanisme bagi suatu organisasi untuk secara sukarela mengintegrasikan perhatian terhadap lingkungan dan sosial ke dalam operasi dan interaksinya dengan stakeholders, yang melebihi tanggung jawab organisasi di bidang hukum. (Darwin, 2004 dalam Suaryana \& Astyari, 2012).

Disiplin akuntasi merespon perkembangan pertanggungjawaban sosial perusahaan yaitu dengan melahirkan wacana baru, yaitu: (1) Social Responsibility Accounting (SRA) yang bertujuan untuk mengungkapkan item - item individual yang mempunyai dampak sosial, (2) Total Impact Accounting (TIA) yang meliputi pengaruh seluruh biaya yang ditanggung oleh perusahaan sebagai akibat operasi usaha yang dijalankan, baik biaya privat maupun biaya publik, dan (3) Sosio Economic Accounting (SEA) yang didefinisikan oleh Linowes sebagai penerapan akuntansi di bidang ilmu sosial yang meliputi ilmu pengetahuan masyarakat, ilmu pengetahuan politik, dan ilmu pengetahuan ekonomi. (Belkaoui, 2000 dalam Yuliana, 2010)

Konflik kepentingan sering kali muncul saat dua pihak memiliki tujuan yang sama, namun sudut pandang atau cara yang ditempuh untuk mencapai tujuan tersebut sering tidak sejalan dengan keinginan masing - masing pihak. Perlu adanya perjanjian tertulis yang menyatakan bahwa ada pihak yang memberikan wewenang (principal), dan ada pihak yang dapat bertidak sesuai dengan wewenang yang diberikan (agent). Teori keagenan menyatakan bahwa principal mendelegasikan tugas atau pekerjaan kepada agent, dimana agent diharapkan 
akan bertindak sesuai dengan kepentingan principal nya (Jensen \& Meckling, 1976; Fong \& Tosi Jr, 2007).

Principal, dalam hal ini adalah pemegang saham, menginginkan kinerja keuangan perusahaan terus meningkat sehingga dapat memberikan nilai tambah bagi mereka. Oleh karena itu, principal akan melakukan pengawasan dengan semestinya agar harapan mereka dapat tercapai. Sementara agents, dalam hal ini adalah direksi atau manajer, perlu mengambil tindakan - tindakan terkait pelaksanaan operasional perusahaan dengan efisien dan efektif tanpa mengurangi kewajiban perusahaan terhadap para pemangku kepentingan (stakeholders) nya, diantaranya; terhadap masyarakat tempat perusahaan tersebut beroperasi, lingkungan hidup, lembaga - lembaga sosial, dan sebagainya. Hal tersebut dapat menimbulkan masalah keagenan yang menyebabkan adanya biaya kontrak dan biaya pengawasan.

Teori keagenan menyatakan bahwa perusahaan yang menghadapi biaya kontrak dan biaya pengawasan yang rendah cenderung akan melaporkan laba lebih rendah atau dengan kata lain akan mengeluarkan biaya-biaya untuk kepentingan manajemen (salah satunya biaya yang dapat meningkatkan reputasi perusahaan di mata masyarakat yaitu biaya-biaya yang terkait dengan tanggung jawab sosial perusahaan) (Febrina \& Suaryana, 2011).

Perusahaan dalam menjalankan aktivitas usahanya tidak hanya memenuhi kewajibannya secara ekonomis terhadap para pemegang saham, tetapi juga ikut bertanggung jawab secara sosial terhadap para pemangku kepentingan (stakeholders). Masyarakat dan lingkungan tempat perusahaan tersebut melakukan aktivitas usahanya merupakan pemangku kepentingan yang paling merasakan dampak langsung maupun tidak langsung dari keberadaan perusahaan.

Stakeholder sendiri adalah setiap kelompok atau individu yang dapat mempengaruhi atau dipengaruhi oleh pencapaian tujuan organisasi. (Freeman \& McVea, 2001 dalam Utama \& Kurniawati, 2012).

Beberapa penelitian terkait pengaruh karakteristik perusahaan terhadap pengungkapan tanggung jawab sosial perusahaan telah banyak dilakukan, di antaranya oleh Yuliana et al. (2008), Febrina \& Suaryana (2011), Sari (2012), Kamil \& Herusetya (2012), Lucyanda \& Siagian (2012), Baehaki (2013), dan Politon \& Rustiyaningsih (2013). Penelitian yang dilakukan para peneliti tersebut bertujuan untuk menjelaskan pengaruh dari beberapa dari sekian banyak karakteristik perusahaan terhadap pengungkapan tanggung jawab sosial perusahaan.

Karakteristik perusahaan sendiri dapat digambarkan sebagai faktor - faktor yang melekat di dalam perusahaan, seperti struktur kepemilikan, ukuran perusahaan, profil perusahaan, ukuran dewan komisaris, leverage, status pencatatan, tipe industri, tujuan internal perusahaan, pertumbuhan perusahaan, dan dividen (Febrina \& Suaryana, 2011).

Dari beberapa karakteristik tersebut, variabel leverage digunakan di dalam penelitian Febrina \& Suaryana (2011), Sari (2012), Lucyanda \& Siagian (2012), Kamil \& Herusetya (2012), serta Politon \& Rustiyaningsih (2013). Febrina \& Suaryana (2011) menduga bahwa variabel leverage berpengaruh signifikan terhadap pengungkapan tanggung jawab sosial perusahaan. Namun, hasil 
penelitian Febrina \& Suaryana (2011) menunjukkan bahwa leverage ternyata tidak berpengaruh terhadap pengungkapan tanggung jawab sosial perusahaan.

Kamil \& Herusetya (2012) dan Politon \& Rustiyaningsih (2013) di lain pihak menduga bahwa variabel leverage berpengaruh positif terhadap pengungkapan tanggung jawab sosial. Walaupun dugaan Kamil \& Herusetya (2012) dan Politon \& Rustiyaningsih sama, namun ternyata hasil penelitian menunjukkan perbedaan. Kamil \& Herusetya (2012) tidak menemukan pengaruh positif tingkat leverage terhadap pengungkapan tanggung jawab sosial perusahaan. Sementara Politon \& Rusityaningsih (2013) membuktikan bahwa tingkat leverage, walaupun tidak signifikan, namun berpengaruh positif terhadap pengungkapan tanggung jawab sosial perusahaan.

Sementara itu, Sari (2012) dan Lucyanda \& Siagian (2012) menduga bahwa tingkat leverage berpengaruh negatif terhadap pengungkapan tanggung jawab sosial perusahaan. Hal tersebut senada dengan hasil penelitian Belkaoui \& Karpik (1989) dalam Setyorini \& Ishak (2012) yang menyatakan bahwa perusahaan dengan tingkat leverage yang tinggi harus patuh pada perjanjian terkait hutang yang harus dilunasi sehingga mengurangi kemampuan perusahaan dalam mengeluarkan dana untuk kepentingan sosial dan lingkungan. Hasil penelitian Sari (2012) dan Lucyanda \& Siagian (2012) menunjukkan bahwa tingkat leverage tidak berpengaruh terhadap pengungkapan tanggung jawab sosial perusahaan.

Variabel profitabilitas, walaupun tidak termasuk dalam karakteristik perusahaan sebagaimana yang disampaikan Febrina \& Suaryana (2011), merupakan variabel yang paling sering digunakan sebagai variabel yang diteliti (Yuliana et al., 2008; Sari 2012; Kamil \& Herusetya 2012; Lucyanda \& Siagian 2012; Baehaki 2013; Politon \& Rustiyaningsih 2013) Para peneliti tersebut menduga bahwa variabel profitabilitas berpengaruh positif terhadap pengungkapan tanggung jawab sosial perusahaan.

Dari beberapa peneliti yang disebutkan di atas, dugaan pengaruh positif profitabilitas terhadap pengungkapan tanggung jawab sosial perusahaan ternyata tidak dapat dibuktikan dalam penelitian Yuliana et al (2008) dan Kamil \& Herusetya (2012) yang hasil penelitiannya menunjukkan bahwa profitabilitas tidak berpengaruh terhadap pengungkapan tanggung jawab sosial perusahaan.

Febrina \& Suaryana (2011) sementara itu menduga variabel profitabilitas berpengaruh signifikan terhadap pengungkapan tanggung jawab sosial perusahaan. Hasil penelitian membuktikan bahwa ternyata profitabilitas tidak berpengaruh terhadap pengungkapan tanggung jawab sosial perusahaan.

Berbagai hipotesis dan hasil penelitian yang berbeda - beda antar satu peneliti dengan peneliti lainnya dalam membuktikan pengaruh profitabilitas dan leverage terhadap pengungkapan tanggung jawab sosial perusahaan mendorong dilakukannya penelitian ini. Perbedaan penelitian ini dengan penelitian sebelumnya terletak pada obyek penelitian dan periode penelitian. Penelitian ini meneliti variabel leverage dan profitabilitas dengan obyek penelitian perusahaan pertambangan yang terdaftar di Bursa efek Indonesia untuk periode 2009 - 2011. Adapun hipotesisnya sebagai berikut :

$\mathrm{H}_{1}$ : Leverage berpengaruh negatif dan signifikan terhadap jumlah pengungkapan tanggung jawab sosial perusahaan. 
$\mathrm{H}_{2}$ : Profitabilitas berpengaruh positif dan signifikan terhadap jumlah pengungkapan tanggung jawab sosial perusahaan.

$\mathrm{H}_{3}$ : Leverage dan Profitabilitas secara simultan berpengaruh signifikan terhadap jumlah pengungkapan tanggung jawab sosial perusahaan.

\section{Metode Penelitian}

Populasi dalam penelitian ini adalah seluruh perusahaan pertambangan yang terdaftar di Bursa Efek Indonesia periode 2009 - 2011. Metode pemilihan sampel dalam penelitian ini dilakukan dengan pendekatan purposive sampling. Purposive sampling adalah teknik penentuan sampel dengan pertimbangan tertentu. Kriteria pemilihan sampel adalah sebagai berikut: (1) Perusahaan pertambangan yang terdaftar di BEI periode 2009 - 201; (2) Perusahaan yang mempublikasikan laporan tahunan yang berakhir tanggal 31 Desember 2009 - 2011; (3) Laporan keuangan yang dipublikasikan periode 2009 - 2011 menggunakan mata uang Rupiah; (4) Laporan keuangan perusahaan tersedia secara lengkap selama tahun 2009 - 2011, baik secara fisik maupun melalui website www.idx.co.id atau pada website masing - masing perusahaan.

Berdasarkan kriteria yang telah ditetapkan, dari total pengamatan sejumlah 30 perusahaan pertambangan, diperoleh 13 sampel perusahaan yang memenuhi kriteria. Perusahaan yang memenuhi kriteria tersebut dapat dilihat pada tabel 1 .

Penelitian ini menggunakan data kuantitatif dan kualitatif. Data kuantitatif yang digunakan dalam penelitian ini meliputi leverage dan profitabilitas. Sementara data kualitatif yang digunakan adalah jenis pengungkapan tanggung jawab sosial perusahaan yang dilakukan oleh perusahaan sampel.

Variabel yang digunakan dalam penelitian ini adalah variabel bebas dan terikat. Variabel bebas merupakan variabel yang mempengaruhi atau yang menjadi sebab perubahannya atau timbulnya variabel dependen (terikat) (Sugiyono, 2012). Variabel bebas dalam penelitian ini adalah leverage dan profitabilitas.

Leverage merupakan risiko keuangan perusahaan yang menggambarkan hubungan total hutang hutang yang dimiliki perusahaan terhadap total aktivanya. Semakin tinggi leverage suatu perusahaan, maka perusahaan memiliki kecenderungan risiko keuangan yang lebih tinggi. Variabel leverage dalam penelitian ini menggunakan alat ukur Debt to Asset Ratio (DAR). DAR merupakan rasio total hutang terhadap total aktiva.

$$
\text { Debt to Asset Ratio (DAR) }=\left\{\frac{\text { Total Hutang }}{\text { Total Aktiva }}\right\}
$$

Profitabilitas menunjukkan perbandingan antara laba dengan aktiva, modal ataupun tingkat penjualan bersih yang digunakan untuk menghasilkan laba tersebut. Profitabilitas dapat mengukur kemampuan perusahaan untuk menghasilkan laba selama periode tertentu. Variabel profitabilitas dalam penelitian ini menggunakan alat ukur Return on Equity (ROE).

ROE merupakan rasio untuk mengukur laba bersih sesudah pajak dengan modal sendiri. Rasio ini menunjukkan efisiensi penggunaan modal sendiri. 
Semakin tinggi rasio, semakin baik. Artinya posisi pemilik perusahaan semakin kuat, demikian pula sebaliknya. Kasmir (2008) dalam Almilia., et al. (2011).

$$
\text { Return on Equity }(\mathrm{ROE})=\left\{\frac{\text { Laba Bersih setelah Pajak }}{\text { Total Ekuitas }}\right\}
$$

Sementara itu, variabel terikat (dependent variable) merupakan variabel yang dipengaruhi atau yang menjadi akibat, karena adanya variabel bebas (Sugiyono, 2012). Variabel terikat dalam penelitian ini adalah jumlah pengungkapan tanggung jawab sosial perusahaan. Pengungkapan tanggung jawab sosial perusahaan merupakan pengungkapan informasi terkait dengan aktivitas sosial perusahaan. Pengungkapan diukur dengan proksi Corporate Social Responsibility Disclosure Index (CSRDI) dan mengacu pada indikator yang dikeluarkan Global Reporting Initiatives (GRI).

Metode pengukuran pengungkapan tanggung jawab sosial perusahaan mengacu pada pengukuran yang pernah dilakukan oleh beberapa peneliti sebelumnya (Jenia, 2011 dan Ahmad, 2011 dalam Baehaki, 2013).

Keterangan:

$$
\operatorname{CSRDI}=\frac{\mathrm{n}}{\mathrm{k}}
$$

CSRDI: Corporate Social Responsibility Disclosure Index perusahaan

$\mathrm{n} \quad$ : Jumlah total pengungkapan tanggung jawab sosial perusahaan

$\mathrm{k} \quad$ : Jumlah maskimal pengungkapan $(\mathrm{k}=79)$

Keterangan:

Skor 0 : Perusahaan tidak mengungkapkan item yang termasuk dalam kategori informasi sosial.

Skor 1 : Perusahaan mengungkapkan item yang termasuk dalam kategori informasi sosial. Semakin banyak item yang diungkapkan oleh perusahaan, maka skornya akan semakin tinggi. Item pengungkapan tanggung jawab sosial terdiri dari 79 item dan mengacu pada pedoman GRI (tabel 2).

Adapun teknik analisis data menggunakan model regresi linier berganda yang dilakukan untuk mengetahui pengaruh dua atau lebih variabel terikat terhadap variabel bebas. Variabel independen dalam penelitian ini adalah leverage dan profitabilitas. Sedangkan variabel dependennya adalah jumlah pengungkapan tanggung jawab sosial perusahaan. Pengujian masing - masing hipotesis dilakukan dengan menguji masing - masing koefisien regresi secara parsial dengan uji $t$ dan secara simultan dengan uji F. Model regresi linear berganda ditunjukkan oleh persamaan berikut ini.

$\mathrm{Y}=\alpha+\beta_{1} \mathrm{X}_{1}+\beta_{2} \mathrm{X}_{2}+\mathrm{e}$

Keterangan:

$\mathrm{Y}=$ Indeks kebijakan pengungkapan tanggung jawab sosial perusahaan

$\mathrm{X}_{1}=$ Leverage

$\mathrm{X}_{2}=$ Profitabilitas

$\alpha=$ Kostanta

$\beta_{1-2}=$ Koefisien regresi

$\mathrm{e}=$ Error 


\section{Hasil dan Pembahasan}

Hasil penghitungan analisis regresi berganda secara parsial dengan alat uji t untuk leverage dan profitabilitas dapat dilihat pada tabel 3. Debt to Asset Ratio (DAR), sebagai alat ukur leverage, menunjukkan nilai signifikansi sebesar 0,115 $(11,5 \%)$. Angka ini menjelaskan bahwa leverage tidak berpengaruh signifikan terhadap kebijakan pengungkapan tanggung jawab sosial perusahaan. Sementara koefisien regresi untuk leverage menunjukkan angka -0,253. Hal ini berarti tingkat leverage berpengaruh negatif terhadap kebijakan pengungkapan tanggung jawab sosial perusahaan. Angka ini menjelaskan bahwa untuk setiap adanya kenaikan tingkat leverage sebesar 1 persen, akan berdampak penurunan atas tingkat pengungkapan tanggung jawab sosial perusahaan sebesar 0,253 persen. Kesimpulan bahwa variabel leverage berpengaruh negatif terhadap pengungkapan tanggung jawab sosial perusahaan sesuai dengan hasil penelitian Kamil \& Herusetya (2012). Sementara tidak signifikannya pengaruh leverage terhadap pengungkapan tanggung jawab sosial perusahaan selaras dengan penelitian Febrina \& Suaryana (2011), Sari (2012), Lucyanda \& Siagian (2012), dan Politon \& Rusityaningsih (2013).

Profitabilitas, dengan alat ukur Return on Equity (ROE), di sisi lain menunjukkan nilai signifikansi sebesar 0,982 (98,2\%). Angka ini menjelaskan bahwa profitabilitas tidak berpengaruh signifikan terhadap kebijakan pengungkapan tanggung jawab sosial perusahaan. Hasil ini sama dengan penelitian yang dilakukan Yuliana et al (2008) dan Kamil \& Herusetya (2012). Sementara koefisien regresi untuk profitabilitas menunjukkan angka 0,002. Hal ini berarti tingkat profitabilitas berpengaruh positif terhadap kebijakan pengungkapan tanggung jawab sosial perusahaan. Angka ini menjelaskan bahwa untuk setiap adanya kenaikan profitabilitas sebesar 1 persen, akan berdampak pada peningkatan atas tingkat pengungkapan tanggung jawab sosial perusahaan sebesar 0,002 persen.

Sementara itu, hasil penghitungan analisis regresi berganda secara simultan dengan alat uji $\mathrm{F}$ untuk leverage dan profitabilitas dapat dilihat pada tabel 4. Hasil uji statistik menunjukkan angka $0,175(17,5 \%)$. Angka tersebut menjelaskan bahwa leverage dan profitabilitas secara simultan tidak berpengaruh signifikan terhadap pengungkapan tanggung jawab sosial perusahaan.

Nilai koefisien determinasi yang diperoleh berdasarkan perhitungan statistik di tabel 5 adalah 0,092 (9,2\%). Nilai ini menunjukkan bahwa variasi leverage dan profitabilitas hanya dapat menjelaskan sebesar $9,2 \%$ terharap variasi pengungkapan tanggung jawab sosial perusahaan. Sementara 90,8\% lainnya dijelaskan oleh faktor lain yang tidak diungkapkan dalam penelitian ini.

\section{Simpulan}

Penelitian ini hanya menggunakan variabel leverage dan profitabilitas dalam mengungkap pengaruhnya terhadap pengungkapan tanggung jawab sosial perusahaan. Alat ukur yang digunakan dalam variabel leverage menggunakan 
DAR, sementara alat ukur yang digunakan dalam variabel profitabilitas menggunakan ROE. Pengungkapan tanggung jawab sosial perusahaan menggunakan pedoman sustainability report yang diterbitkan oleh GRI (2006).

Hasil penghitungan menunjukkan bahwa leverage berpengaruh negatif namun tidak signifikan terhadap pengungkapan tanggung jawab sosial perusahaan. Sementara profitabilitas berpengaruh positif namun tidak signifikan terhadap pengungkapan tanggung jawab sosial perusahaan. Leverage dan profitabilitas secara simultan juga tidak berpengaruh terhadap pengungkapan tanggung jawab sosial perusahaan.

Nilai koefisien determinasi adalah 0,092 (9,2\%). Nilai ini menunjukkan bahwa variasi leverage dan profitabilitas hanya dapat menjelaskan sebesar 9,2\% terhadap variasi pengungkapan tanggung jawab sosial perusahaan. Sementara $90,8 \%$ lainnya dijelaskan oleh faktor lain yang tidak diungkapkan dalam penelitian ini.

Kecilnya nilai koefisien determinasi $(9,2 \%)$ dari variasi leverage dan profitabilitas terhadap variasi pengungkapan tanggung jawab sosial perusahaan menjadikan penelitian ini masih memiliki beberapa kekurangan yang harus diperbaiki dalam penelitian berikutnya. Masih banyak variabel lain yang termasuk dalam karakteristik perusahaan selain leverage dan profitabilitas yang dapat disertakan dalam penelitian selanjutnya untuk dapat mengungkap pengaruhnya terhadap pengungkapan tanggung jawab sosial perusahaan.

Penelitian ini juga hanya menggunakan 13 perusahaan pertambangan yang terdaftar di Bursa Efek Indonesia (BEI) sebagai sampel dengan beberapa kriteria yang telah ditetapkan melalui metode purposive sampling. Sehingga hasil dari penelitian ini tidak dapat digeneralisasi secara luas untuk semua perusahaan yang terdaftar di BEI.

Peneliti menyarankan agar penelitian selanjutnya menyertakan perusahaan dengan jumlah yang lebih banyak dengan tahun pengamatan yang lebih panjang agar memperoleh hasil yang lebih baik.

\section{Daftar Pustaka}

Ahmad Kamil., \& Antonius Herusetya. (2012). Pengaruh Karakteristik Perusahaan Terhadap Luas Pengungkapan Kegiatan Corporate Social Responsibility. Media Riset Akuntansi Vol. 2 No. 1.

Christina Tri Setyorini., \& Zuaini Ishak. (2012). Corporate Social and Environmental Disclosure: A Positive Accounting Theory View Point. International Journal of Business and Social Science Vol. 3. No. 9.

Eki Baehaki. (2013). Faktor - Faktor yang Mempengaruhi Pengungkapan Corporate Social Responsibility (Studi pada Perusahaan Manufaktur dan Pertambangan yang Listing di Bursa Efek Indonesia Tahun 2011). Skripsi. Universitas Pendidikan Indonesia.

Febrina., \& I G N Agung Suaryana. (2011). Faktor - Faktor yang Mempengaruhi Kebijakan Pengungkapan Tanggung Jawab Sosial dan Lingkungan pada Perusahaan Manfaktur di Bursa Efek Indonesia. Simposium Nasional Akuntansi 14. 
Fong, Eric. A., \& Tosi, Jr. Henry. L. (2007). Effort, Performance, and Conscientiousness: An Agency Theory Perspective. Journal of Management, Vol. 33, No. 2.

Global Reporting Initiatives. (2000). Sustainability Reporting Guidelines.

I G N Agung Suaryana., \& Putu Norma Astyari. (2012). Perbedaan Pengaruh Pengungkapan Tanggung Jawab Sosial terhadap Reaksi Pasar antara Perusahaan High - Profile dan Low Profile dalam Indeks LQ - 45 di Bursa Efek Indonesia tahun 2009. Jurnal Riset Akuntansi Vol. 2. No. 1.

I Made Karya Utama., \& Pande Putu Febri Kurniawati. (2012). Faktor - Faktor yang mempengaruhi Luas Pengungkapan Corporate Social Responsibility (Studi pada Perusahaan non Keuangan di Bursa Efek Indonesia). Jurnal Riset Akuntansi Vol. 2. No. 1.

Jensen, M. C., \& Meckling, W. H. (1976). Theory of the Firm: Managerial Behavior, Agency Costs and Ownership Structure. Journal of Financial Economics, 3.

Luciana Spica Almilia., Nurul Hasanah Uswati Dewi., \& Vidiana Hastutik Is Hartono. (2011). Faktor - Faktor yang Mempengaruhi Pengungkapan Tanggung Jawab Sosial dan Dampaknya Terhadap Kinerja Keuangan dan Ukuran Perusahaan. Jurnal Fokus Ekonomi Vol. 10 No.1.

Lucyanda, Jurica., \& Siagian, Lady Graciaprilia. (2012). The Influence of Company Characteristics Toward Corporate Social Responsibility Disclosure. The 2012 International Conference on Business and Management.

Ni Wayan Rustiarini. (2012). Efek Moderasi Corporate Governance pada Hubungan Corporate Social Responsibility dan Nilai Perusahaan. Jurnal Riset Akuntansi Vol. 2. No. 1.

Rita Yuliana., Bambang Purnomosidhi., \& Eko Ganis Sukoharsono. (2008). Pengaruh Karakteristik Perusahaan Terhadap Pengungkapan Corporate Social Responsibility (CSR) dan Dampaknya Terhadap Reaksi Investor. Jurnal Akuntansi dan Keuangan Indonesia Volume 5 - Nomor 2.

Rita Yuliana. (2010). Praktik Pengungkapan Corporate Social Responsibility (CSR) di Indonesia (Studi pada Perusahaan yang Terdaftar di BEI). Jurnal Investasi Vol. 6 No.2.

Rizkia Anggita Sari. (2012). Pengaruh Karakteristik Perusahaan terhadap Corporate Social Responsibility Disclosure pada Perusahaan Manufaktur yang terdaftar di Bursa Efek Indonesia. Jurnal Nominal Volume 1 Nomor 1.

Sontry Oktaviana Politon., \& Sri Rustiyaningsih. (2013). Karakteristik Perusahaan Pengungkapan Tanggung Jawab Sosial pada Perusahaan Manufaktur Go Publik. Jurnal Riset Manajemen dan Akuntansi Vol. 1 No. 1.

Sugiyono. (2012). Metode Penelitian Kuantitatif dan Kualitatif dan $R \& D$. Alfabeta.

Keputusan Ketua Bapepam dan LK No. Kep-134/BL/2006

Pernyataan Standar Akuntansi Keuangan No. 1 tahun 2009 (revisi 1998)

Undang - Undang Perseroan Terbatas tahun 2007 


\section{TABEL}

\section{Tabel 1}

Jumlah Pengamatan Perusahaan Pertambangan

Jumlah perusahaan pertambangan terdaftar di BEI tahun 2009 - 30 Perusahaan 2011

Tidak mempublikasikan laporan tahunan secara konsisten tahun 11 Perusahaan 2009-2011

Publikasi laporan keuangan menggunakan mata uang asing 5 Perusahaan tahun 2009-2011

\begin{tabular}{ll}
\hline Data Perusahaan yang tidak dapat digunakan dalam penelitian & 1 Perusahaan \\
\hline Total Sampel Penelitian & 13 Perusahaan \\
\hline Sumber: www.idx.co.id dan website masing - masing perusahaan (diolah)
\end{tabular}

\section{Tabel 2}

\section{Daftar Item Pengungkapan Tanggung Jawab Sosial Perusahaan menurut} GRI

\begin{tabular}{lll}
\hline No. & Kode & KETERANGAN \\
\hline 1 & EC1 & Perolehan dan distribusi nilai ekonomi langsung \\
\hline 2 & EC2 & Implikasi finansial dan risiko lainnnya \\
\hline 3 & EC3 & Jaminan kewajiban organisasi terhadap program imbalan pasti \\
\hline 4 & EC4 & Bantuan finansial yang signifikan dari pemerintah \\
\hline 5 & EC5 & Rentang rasio standar upah terendah \\
\hline 6 & EC6 & Kebijakan, praktek, dan proporsi pengeluaran untuk pemasok local \\
\hline 7 & EC7 & $\begin{array}{l}\text { Prosedur penerimaan pegawai lokal dan proporsi manajemen } \\
\text { senior local }\end{array}$ \\
\hline 8 & EC8 & $\begin{array}{l}\text { Pembangunan infrastruktur yang diberikan untuk kepentingan } \\
\text { publik }\end{array}$ \\
\hline 9 & EC9 & Dampak ekonomi tidak langsung yang signifikan \\
\hline 10 & EC10 & Penggunaan Bahan, diperinci berdasarkan berat atau volume \\
\hline 11 & EC11 & Persentase Penggunaan Bahan Daur Ulang \\
\hline 12 & EN1 & Penggunaan Energi Langsung dari Sumberdaya Energi Primer \\
\hline 14 & EN2 & Pemakaian Energi Tidak Langusng berdasarkan Sumber Primer \\
\hline 15 & EN4 & $\begin{array}{l}\text { Penghematan Energi melalui Konservasi dan Peningkatan } \\
\text { Efisiensi }\end{array}$ \\
\hline 16 & EN5 & $\begin{array}{l}\text { Inisiatif untuk mendapatkan produk dan jasa berbasis energi } \\
\text { pengurangan yang dicapai }\end{array}$ \\
\hline 17 & EN6 & Total pengambilan air per sumber \\
\hline 18 & EN7 & $\begin{array}{l}\text { Sumber air yang terpengaruh secara signifikan akibat pengambilan } \\
\text { air }\end{array}$ \\
\hline 19 & EN8 & Keanekaragaman hayati \\
\hline & & \\
\hline
\end{tabular}




\begin{tabular}{|c|c|c|}
\hline 20 & EN9 & Lokasi yang berdekatan dengan daerah yang diproteksi \\
\hline 21 & EN10 & $\begin{array}{l}\text { Uraian atas dampak signifikan terhadap keanekaragaman hayati di } \\
\text { daerah yang diproteksi }\end{array}$ \\
\hline 22 & EN11 & Perlindungan dan Pemulihan habitat \\
\hline 23 & EN12 & $\begin{array}{l}\text { Strategi, tindakan, dan rencana untuk mengelola dampak terhadap } \\
\text { keanekaragaman hayati }\end{array}$ \\
\hline 24 & EN13 & Jumlah spesies berdasarkan tingkat risiko kepunahan \\
\hline 25 & EN14 & $\begin{array}{l}\text { Jumlah emisi gas rumah kaca yang sifatnya langsung maupun } \\
\text { tidak langsung }\end{array}$ \\
\hline 26 & EN15 & Emisi gas rumah kaca tidak langsung lainnya \\
\hline 27 & EN16 & $\begin{array}{l}\text { Inisiatif untuk mengurangi emisi gas rumah kaca dan } \\
\text { pencapaiannya }\end{array}$ \\
\hline 28 & EN17 & Emisi bahan kimia yang merusak lapisan ozon \\
\hline 29 & EN18 & NOx,SOx dan emisi udara signifikan lainnya \\
\hline 30 & EN19 & Jumlah dan volume tumpahan yang signifikan \\
\hline 31 & EN20 & Jumlah buangan air menurut kualitas dan tujuan \\
\hline 32 & EN21 & Jumlah berat limbah menurut jenis dan metode pembuangan \\
\hline 33 & EN22 & $\begin{array}{l}\text { Berat limbah yang diangkut, diimpor, dieskpor, atau diolah yang } \\
\text { dianggap berbahaya }\end{array}$ \\
\hline 34 & EN23 & Nilai keanekaragaman yang dipengaruhi oleh pembuangan \\
\hline 35 & EN24 & Inisiatif untuk mengurangi dampak lingkungan produk dan jasa \\
\hline 36 & EN25 & $\begin{array}{l}\text { Persentase produk terjual dan bahan kemasannya yang ditarik } \\
\text { menurut kategori }\end{array}$ \\
\hline 37 & EN26 & $\begin{array}{l}\text { Nilai moneter denda yang signifikan atas pelanggaran hukum dan } \\
\text { regulasi lingkungan }\end{array}$ \\
\hline 38 & EN27 & Dampak lingkungan yang signifikan akibat pemindahan produk \\
\hline 39 & EN28 & $\begin{array}{l}\text { Jumlah pengeluaran untuk proteksidan investasi lingkungan } \\
\text { menurut jenis }\end{array}$ \\
\hline 40 & LA1 & $\begin{array}{l}\text { Jumlah angkatan kerja menurut jenis pekerjaan, kontrak pekerjaan, } \\
\text { dan wilayah }\end{array}$ \\
\hline 41 & LA2 & $\begin{array}{l}\text { Jumlah dan tingkat perputaran karyawan menurut kelompok usia, } \\
\text { jenis kelamin, dan wilayah }\end{array}$ \\
\hline 42 & LA3 & Manfaat yang disediakan bagi karyawan \\
\hline 43 & LA4 & $\begin{array}{l}\text { Persentase karyawan yang dilindungi perjanjian tawar-menawar } \\
\text { kolektif }\end{array}$ \\
\hline 44 & LA5 & Masa pemberitahuan minimal tentang perubahan kegiatan penting \\
\hline 45 & LA6 & $\begin{array}{l}\text { Rasio jumlah angkatan kerja yang resmi diwakili dalam panitia } \\
\text { kesehatan }\end{array}$ \\
\hline 46 & LA7 & Hari-hari yang hilang dan jumlah kematian karena pekerjaan \\
\hline 47 & LA8 & Program pendidikan dan pelatihan untuk para karyawan \\
\hline 48 & LA9 & $\begin{array}{l}\text { Masalah kesehatan dan keselamatan yang tercakup dalam } \\
\text { perjanjian resmi }\end{array}$ \\
\hline 49 & LA10 & Rata-rata jam pelatihan tiap tahun tiap karyawan \\
\hline 50 & LA11 & $\begin{array}{l}\text { Program untuk pengaturan keterampilan dan pembelajaran } \\
\text { karyawan }\end{array}$ \\
\hline
\end{tabular}




\begin{tabular}{|c|c|c|}
\hline 51 & LA12 & $\begin{array}{l}\text { Persentase karyawan yang menerima peninjauan kinerja dan } \\
\text { pengembangan karier }\end{array}$ \\
\hline 52 & LA13 & Komposisi badan pengelola/penguasa \\
\hline 53 & LA14 & $\begin{array}{l}\text { Perbandingan/rasio gaji dasar pria terhadap wanita menurut } \\
\text { kelompok/kategori karyawan }\end{array}$ \\
\hline 54 & LA15 & $\begin{array}{l}\text { Persentase dan jumlah perjanjian investasi signifikan yang memuat } \\
\text { klausul HAM }\end{array}$ \\
\hline 55 & LA16 & $\begin{array}{l}\text { Persentase pemasok dan kontraktor yang telah menjalani } \\
\text { skrining/filtrasi aspek HAM }\end{array}$ \\
\hline 56 & LA17 & Jumlah waktu pelatihan bagi karyawan terkait dengan aspek HAM \\
\hline 57 & LA18 & $\begin{array}{l}\text { Jumlah kasus diskriminasi yang terjadi dan tindakan yang } \\
\text { diambil/dilakukan }\end{array}$ \\
\hline 58 & LA19 & $\begin{array}{l}\text { Segala kegiatan berserikat dan berkumpul yang teridentifikasi } \\
\text { dapat menimbulkan risiko }\end{array}$ \\
\hline 59 & LA20 & Kegiatan yang mengandung risiko terjadinya kasus pekerja anak \\
\hline 60 & LA21 & $\begin{array}{l}\text { Kegiatan yang mengandung risiko menimbulkan terjadinya kasus } \\
\text { kerja paksa atau kerja wajib }\end{array}$ \\
\hline 61 & LA22 & $\begin{array}{l}\text { Rasio personel keamanan terkait dengan aspek HAM yang relevan } \\
\text { dengan kegiatan organisasi }\end{array}$ \\
\hline 62 & LA23 & Jumlah kasus pelanggaran yang terkait dengan hak penduduk asli \\
\hline 63 & LA24 & Keefektifan setiap program yang dilakukan terhadap masyarakat \\
\hline 64 & LA25 & $\begin{array}{l}\text { Persentase dan jumlah unit usaha yang memiliki risiko terhadap } \\
\text { korupsi }\end{array}$ \\
\hline 65 & LA26 & $\begin{array}{l}\text { Persentase pegawai yang dilatih dalam kebijakan dan prosedur } \\
\text { antikorupsi }\end{array}$ \\
\hline 66 & LA27 & Tindakan yang diambil dalam menanggapi kejadian korupsi \\
\hline 67 & LA28 & $\begin{array}{l}\text { Kedudukan kebijakan dalam proses melobi dan pembuatan } \\
\text { kebijakan publik }\end{array}$ \\
\hline 68 & LA29 & $\begin{array}{l}\text { Nilai kontribusi finansial dan natura kepada institusi terkait } \\
\text { dimana perusahaan beroperasi }\end{array}$ \\
\hline 69 & LA30 & $\begin{array}{l}\text { Jumlah pelanggaran ketentuan antipersaingan, anti-trust, dan } \\
\text { praktek monopoli }\end{array}$ \\
\hline 70 & LA31 & Nilai denda atas pelanggaran hukum dan peraturan \\
\hline 71 & PR1 & $\begin{array}{l}\text { Tahapan daur hidup dari kategori produk dan jasa yang terpenting } \\
\text { yang harus mengikuti prosedur }\end{array}$ \\
\hline 72 & PR2 & $\begin{array}{l}\text { Jumlah pelanggaran terhadap peraturan mengenai damapak } \\
\text { kesehatan dan keselamatan produk }\end{array}$ \\
\hline 73 & PR3 & Jenis informasi produk dan jasa yang dipersyaratkan \\
\hline 74 & PR4 & $\begin{array}{l}\text { Jumlah pelanggran mengenci penyediaan informasi produk dan } \\
\text { jasa serta pemberian label }\end{array}$ \\
\hline 75 & PR5 & Praktek yang mengukur kepuasan pelanggan (survey) \\
\hline 76 & PR6 & Program-program untuk ketaatan pada hokum \\
\hline 77 & PR7 & Jumlah pelanggaran peraturan mengenai komunikasi pemasaran \\
\hline 78 & PR8 & $\begin{array}{l}\text { Jumlah pengaduan mengenai pelanggaran keleluasaan pribadi } \\
\text { (privacy) pelanggan }\end{array}$ \\
\hline
\end{tabular}


79 PR9 Nilai denda pelanggaran hukum mengenai pengadaan dan penggunaan produk dan jasa

Sumber: GRI (diolah)

\section{Tabel 3}

\begin{tabular}{|c|c|c|c|c|c|c|}
\hline \multicolumn{7}{|c|}{ Coefficients $^{\mathrm{a}}$} \\
\hline \multirow[b]{2}{*}{ Model } & & \multicolumn{2}{|c|}{$\begin{array}{l}\text { Unstandardized } \\
\text { Coefficients }\end{array}$} & \multirow{2}{*}{$\begin{array}{c}\begin{array}{c}\text { Standardized } \\
\text { Coefficients }\end{array} \\
\text { Beta }\end{array}$} & \multirow[b]{2}{*}{$\mathrm{t}$} & \multirow[b]{2}{*}{ Sig. } \\
\hline & & $\mathrm{B}$ & Std. Error & & & \\
\hline 1 & (Constant) &, 376 &, 087 & & 4,329 &, 000 \\
\hline & DAR &,- 253 &, 156 &,- 302 & $-1,615$ &, 115 \\
\hline & ROE &, 002 &, 084 &, 004 &, 022 &, 982 \\
\hline
\end{tabular}

a. Dependent Variable: CSR

\section{Regresi Linear Berganda - Parsial}

\section{Tabel 4}

Regresi Linier Berganda - Simultan

\begin{tabular}{|c|c|c|c|c|c|c|}
\hline \multicolumn{7}{|c|}{ ANOVA $^{b}$} \\
\hline & & $\begin{array}{l}\text { Sum of } \\
\text { Squares }\end{array}$ & $\mathrm{df}$ & Mean Square & $\mathrm{F}$ & Sig. \\
\hline \multirow[t]{3}{*}{1} & Regression &, 098 & 2 &, 049 & 1,830 &, $175^{\mathrm{a}}$ \\
\hline & Residual & ,965 & 36 &, 027 & & \\
\hline & Total & 1,063 & 38 & & & \\
\hline
\end{tabular}

a. Predictors: (Constant), ROE, DAR

b. Dependent Variable: CSR

\section{Tabel 5}

Koefisien determinasi

Model Summary

Model R R Square

$1 \quad, 304^{\mathrm{a}} \quad, 092$

a. Predictors: (Constant), ROE, DAR

b. Dependent Variable: CSR 